\title{
Perception and Motivation and Its Effect on the Farmers Decision to Conduct Beef Cattle Business Partnership System (Teseng)
}

\author{
ST. Rohani ${ }^{1}$, AR Siregar ${ }^{1}$, TG Rasyid ${ }^{1}$, M Aminawar ${ }^{1}$, M Darwis $^{2}$ \\ ${ }^{1}$ Faculty of Animal Science, Hasanuddin University. \\ ${ }^{2)}$ Center for Research and Development of the Dynamics of Society, Culture and Humanities Institute for Research and Community Service \\ Hasanuddin University Street Perintis Kemerdekaan KM. 10 Tamalanrea, Makassar, South Sulawesi Province-Indonesia. \\ E-mail: strohani@unhas.ac.id
}

Received date: 12 February 2019, Accepted date: 15 May 2019, Online date: 3 June 2019

\section{Address for Correspondence:}

ST. Rohani, Faculty of Animal Science, Hasanuddin University.

E-mail: strohani@unhas.ac.id

Copyright $(2019$ by authors and American-Eurasian Network for Scientific Information.

This work is licensed under the Creative Commons Attribution International License (CC BY).

http://creativecommons.org/licenses/by/4.0/

\section{(c) (i) Open Access}

\begin{abstract}
Beef cattle business management through the teseng system must be well perceived by farmers so that they are motivated to carry out beef cattle business so that it can influence the decision of farmers to carry out business cooperation through the teseng system. This study aims to: (1) describe the perceptions of beef cattle farmers on the teseng system; (2) describe the motivation of beef cattle farmers to the teseng system; and (3) analyze the effect of perception and motivation on the decision of farmers to conduct beef cattle business partnership (teseng) in Bone Regency. This research uses descriptive and explanatory research types. The sampling technique was carried out by simple random sampling of 150 farmers consisting of 90 people who did the teseng system and 60 people who did not do the teseng system in Patimpeng, Kahu and Libureng Districts. Data collection was carried out through interviews and focus group discussions which were analyzed using descriptive statistics and logistic regression. The results showed that: (1) variable perception of farmers against the test system consisting of sub variables: (a) economic benefits, (b) technical advantage, (c) the application of the teseng system is easier, (d) the level of conformity with the local community is in the good category; (2) farmer motivation variables on the teseng system which consists of sub-variables: (a) family economic demands, (b) limited business capital, (c) requests of friends/close relatives, (d) improve social status, (e) there is free time, (f) the chance of getting greater results, (g) additional income, (h) accept the trust and responsibility of raising cows in the good category; and (3) perceptions and motivations have a significant effect on the decision of farmers to do the teseng system.
\end{abstract}

KEYWORDS

Perception, motivation, decision, farmers, teseng system, beef cattle

\section{INTRODUCTION}

The livestock business is currently giving very positive new hope to improve the welfare of farmers in increasing their income. However, it must be accompanied by the existence of a good and appropriate farm management pattern from the technical side as well as from the management side.

The demand for meat continues to increase from year to year and government support efforts to encourage the development of beef cattle business so that it can be a motivation for farmers to further develop their beef cattle business as an effort to meet the needs of farmers and their families. According to [1], beef 
cattle are the most significant contributor to the production of beef and have not been able to meet domestic demand, which tends to increase every year.

The growth of the livestock sub-sector contributes quite significantly to agricultural development and the rural economy. However, the condition of animal husbandry in rural areas is often constrained by several factors, one of which is always dealing with capital problems for business development. Government assistance in supporting the development of beef cattle includes assistance and facilities, such as cattle fattening loans, beef cattle breeding credits, implementation of a contract system through the development of beef cattle and livestock noise systems. According to [2], business development through some cattle partnership is an alternative to improve the profitability of farmers and could overcome some of the problems in the beef cattle business, namely small-scale cattle raising and limited capital.

Bone Regency is one of the central areas of beef cattle development in South Sulawesi where farmers develop beef cattle business by implementing a profit-sharing business partnership system (teseng). The existence of farmers doing a teseng system is seen positively as one way to achieve the goal to improve the welfare of farmers who do a teseng system. In general, farmers who carry out a teseng system are farmers who have experience in conducting a teseng system that ranges between 5-10 years. Experience in conducting a teseng system provides a good perception so that spurred farmers motivation to keep doing the teseng system.

In Bone Regency, the teseng system involves two parties, namely between the capitalist and the farmers. The party that gives capital is the party that owns the cattle but does not have enough time to raise the cattle, so the capital owner (Ma'teseng) gives the cattle to the farmer (Pa'teseng) to be raised in accordance with the agreements and agreements that are built previously. According to the farmers, the agreement that was built was not done in writing between the farmer (Pa'teseng) and the owner of the capital (Ma'teseng), but only prioritized the concept of trust or kinship so that the distribution of the results was sometimes unfavorable for the farmer (Pa'teseng). Although it is less profitable for farmers to continue to implement the profit-sharing system because farmers are motivated by various things that affect it.

According to [3], that the profit-sharing system is a concept of revenue sharing that is very easy to understand and apply because in addition to the easy application because it does not require complicated requirements it is also very easy to accept because this system can be said to be rooted in the lives of the local community and very beneficial between livestock owners and farmers or people who keep livestock.

The strong desire of farmers to keep doing the teseng system opens opportunities for farmers to meet the needs of their families lives, the necessities of life that are increasingly encouraging farmers to survive doing the teseng system. In addition to the need factor, which encourages farmers to continue to do the teseng system is a good perception of farmers on the teseng system so that farmers can understand and understand the mechanisms and patterns that apply to the teseng system. This perception is usually influenced by internal and external factors of farmers who carry out the teseng system.

This study aims to: (1) describe the perceptions of beef cattle farmers on the teseng system; (2) describe the motivation of beef cattle farmers to the teseng system; and (3) analyze the effect of perception and motivation on the decision of farmers to conduct beef cattle business partnership (teseng) in Bone Regency.

\section{RESEARCH METHODS}

This research was conducted from May to July 2019 in Patimpeng District, Kahu District, and Libureng District, Bone Regency by using descriptive and explanatory research types. The sampling technique was carried out by simple random sampling of 150 farmers consisting of 90 people who did the teseng system and 60 people who did not do the teseng system in Patimpeng, Kahu and Libureng Districts. Data collection was carried out through interviews and focus group discussions which were analyzed using descriptive statistics and logistic regression [3].

Description of the variable perception farmers a teseng system with sub variables: (a) economic benefits, (b) technical advantages, (c) easier application of the teseng system, (d) the level of conformity with the local community. The measurement using a Likert scale is a score of 1 to 3 with category $1=\operatorname{not}$ good; $2=$ less good; and 3 = good. Variables of farmers perceptions measured by class range are as follows:

Highest score $=$ Highest weight $\mathrm{x}$ number of respondents $\mathrm{x}$ number of questions

$\begin{array}{lllll}(3) & \mathrm{X} & (150) & \mathrm{X} & \text { (4) }\end{array}$

Lowest score $\quad=$ Lowest weight $\mathrm{x}$ number of respondents $\mathrm{x}$ number of questions
(1)
(150)
$\mathrm{x} \quad(4)$
$=600$

Class range

$=\frac{\text { Highest score }- \text { Lowest score }}{\text { Number of Classes }}=\frac{1800-600}{3}=400$

From these values can be made the following categories: 


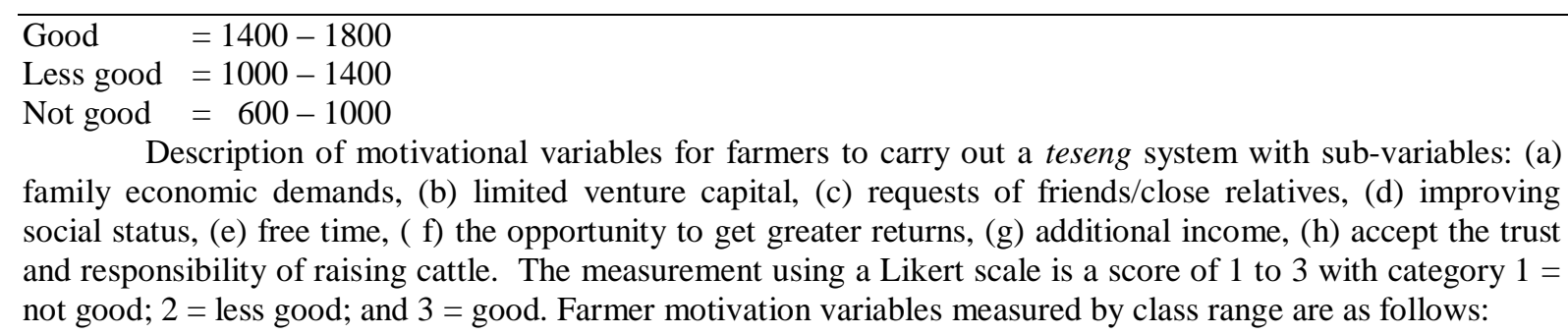

Highest score $\quad=$ Highest weight $\mathrm{x}$ number of respondents $\mathrm{x}$ number of questions

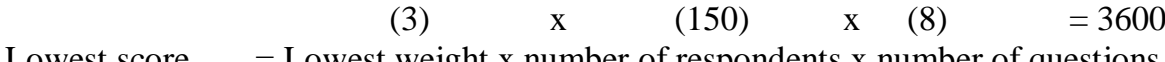
(1)
$\mathrm{X}$
(150)
(8)
$=1200$

Class range $=\frac{\text { Highest score }- \text { Lowest score }}{\text { Number of Classes }}=\frac{3600-1200}{3}=800$

From these values can be made the following categories:

Good $=2800-3600$

Less good $=2000-2800$

Not good $=1200-2000$

Analysis of the effect of perceptions and motivation variables on the decision of farmers to use the teseng system used logistic regression. The mathematical model of logistic regression can be written as follows:

$\log \left(\frac{P}{1-P}\right)=\beta_{0}+\beta_{1} \mathrm{X}_{1}+\beta_{2} \mathrm{X}_{2}$

Where:

$\mathrm{p}=$ Opportunities for farmers to carry out value teseng systems $\mathrm{Y}=1$; not doing a value teseng system $\mathrm{Y}=0$.

$\beta_{1}$ and $\beta_{2}=$ Variable Regression Coefficient $X_{1}$ and $X_{2}$

$\mathrm{X}_{1} \quad=$ Farmer Perception (score)

$\mathrm{X}_{2} \quad=$ Farmer motivation (score)

\section{RESULTS AND DISCUSSION}

Perception of Farmers Conducting a Beef Cattle Business Partnership System (Teseng) in Bone Regency.

Perception in the form of responses given by farmers to the teseng system in Bone Regency. Description of the variable perception farmers a teseng system which consists of sub variables: (a) economic benefits, (b) technical advantages, (c) easier application of the teseng system, (d) the level of conformity with the local community. A description of the results of the study of the farmer perception variable can be seen in Table 1 .

Table 1. Perception of Farmers Conducting a Beef Cattle Business Partnership System (Teseng) in Bone Regency.

\begin{tabular}{|c|l|c|c|c|c|}
\hline Number & Farmer Perception Variable & Score & $\begin{array}{c}\text { Frequency } \\
\text { (Person) }\end{array}$ & $\begin{array}{c}\text { Percentage } \\
(\boldsymbol{\%})\end{array}$ & $\begin{array}{c}\text { Value } \\
\text { (Score x Frequency) }\end{array}$ \\
\hline 1. & Economic benefits & 3 & 121 & 80,7 & 363 \\
& Good & 2 & 23 & 15,3 & 46 \\
& Less good & 1 & 6 & 4 & 6 \\
\hline & Not good $\quad$ Total & & $\mathbf{1 5 0}$ & $\mathbf{1 0 0}$ & $\mathbf{4 1 5}$ \\
\hline \multicolumn{2}{|c|}{} & 3 & 119 & 79,3 & 357 \\
& Technical advantage & 2 & 31 & 20,7 & 62 \\
& Good & 1 & 0 & - & 0 \\
\hline
\end{tabular}


ST. Rohani et al., 2019. Perception and Motivation and Its Effect on the Farmers Decision to Conduct Beef Cattle Business Partnership System (Teseng) /American-Eurasian Journal of Sustainable Agriculture. 13(2): 68-76. DOI: 10.22587/aejsa.2019.13.2.8

\begin{tabular}{|c|c|c|c|c|c|}
\hline \multicolumn{2}{|r|}{ Total } & & 150 & 100 & 419 \\
\hline 3. & $\begin{array}{l}\text { Implementation of the Teseng } \\
\text { system is easier } \\
\text { Good } \\
\text { Less good } \\
\text { Not good }\end{array}$ & $\begin{array}{l}3 \\
2 \\
1\end{array}$ & $\begin{array}{c}137 \\
13 \\
0\end{array}$ & $\begin{array}{c}91,3 \\
8,7 \\
-\end{array}$ & $\begin{array}{c}411 \\
26 \\
0\end{array}$ \\
\hline \multicolumn{2}{|r|}{ Total } & & 150 & 100 & 437 \\
\hline 4. & $\begin{array}{l}\text { The level of compatibility with } \\
\text { the local community } \\
\text { Good } \\
\text { Less good } \\
\text { Not good }\end{array}$ & $\begin{array}{l}3 \\
2 \\
1\end{array}$ & $\begin{array}{c}133 \\
11 \\
6\end{array}$ & $\begin{array}{c}88,7 \\
7,3 \\
4\end{array}$ & $\begin{array}{c}399 \\
22 \\
6\end{array}$ \\
\hline \multicolumn{2}{|r|}{ Total } & & 150 & 100 & 427 \\
\hline \multicolumn{5}{|c|}{ Total Score } & 1698 \\
\hline
\end{tabular}

Source: Primary Data after Processed, 2019.

Table 1 shows that the total score for farmer's perceptions of assessment using a teseng system consists of sub variables: (a) economic benefits, (b) technical benefits, (c) easier application of the teseng system, (d) the level of conformity with the local community is 1698. The results of this study are in the Good Category (1400 - 1800). The results of this study can be said that farmers provide a good perception of the teseng system in Bone Regency.

The mechanism applied to the teseng system is very easy and mutually beneficial between livestock owners and farmers. Teseng system is a concept of agreement based on aspects of trust between livestock owners and farmers in raising their livestock.

Beef cattle farmers in Bone Regency feel the teseng system is very appropriate to be applied in the lives of farmers. The characteristics of the Bugis community who uphold the attitude of mutual trust are very influential in the successful implementation of the teseng system, moreover the teseng system can be said to be a social investment for livestock owners for people who care for their animals.

The mechanism of implementing the teseng system is felt to be quite easy because the teseng system is a business cooperation system that has existed for a long time and is carried on from generation to generation by the people in Bone Regency.

According to [5], that teseng is usually applied to farms with a mechanism of income sharing between farmers and owners of capital but the implementation and form of agreements may vary. While [6], that the availability of capital for rural people, especially beef cattle farmers is very limited. Therefore, external financing is very helpful in run breeding cattle. Financing may include internal and external financing. [7], therefore, in a modern or traditional profit-sharing system, both capital owners and beef breeders get the same benefit. The partnership pattern is usually established between farmers and companies (investors) with some models.

\section{Motivation of Farmers to Conduct a Beef Cattle Business Partnership System (Teseng) in Bone Regency.}

Farmers have a strong desire to increase the income and welfare of their families so that farmers are motivated to do beef cattle farming better. Farmer motivation variables consisting of sub variables: (a) family economic demands, (b) limited venture capital, (c) requests of friends/close relatives, (d) improving social status, (e) free time, (f) opportunities get greater returns, (g) additional income, (h) accept the trust and responsibility of raising cows. A description of the results of the study of farmer motivation variables can be seen in Table 2.

Table 2. Motivation of Farmers to Conduct a Beef Cattle Business Partnership System (Teseng) in Bone Regency.

\begin{tabular}{|c|l|c|c|c|c|}
\hline Number & Farmer Motivation Variable & Score & $\begin{array}{c}\text { Frequency } \\
\text { (Person) }\end{array}$ & $\begin{array}{c}\text { Percentage } \\
(\boldsymbol{\%})\end{array}$ & $\begin{array}{c}\text { Value } \\
\text { (Score x Frequency) }\end{array}$ \\
\hline 1. & Family economic demands & & & & \\
& Good & 3 & 107 & 71,3 & 321 \\
& Less good & 2 & 43 & 28,7 & 86 \\
& Not good & 1 & 0 & - & 0 \\
\hline \multicolumn{1}{|r|}{ Total } & & $\mathbf{1 5 0}$ & $\mathbf{1 0 0}$ & $\mathbf{4 0 7}$ \\
\hline
\end{tabular}


ST. Rohani et al., 2019. Perception and Motivation and Its Effect on the Farmers Decision to Conduct

Beef Cattle Business Partnership System (Teseng) /American-Eurasian Journal of Sustainable Agriculture. 13(2): 68-76. DOI: 10.22587/aejsa.2019.13.2.8

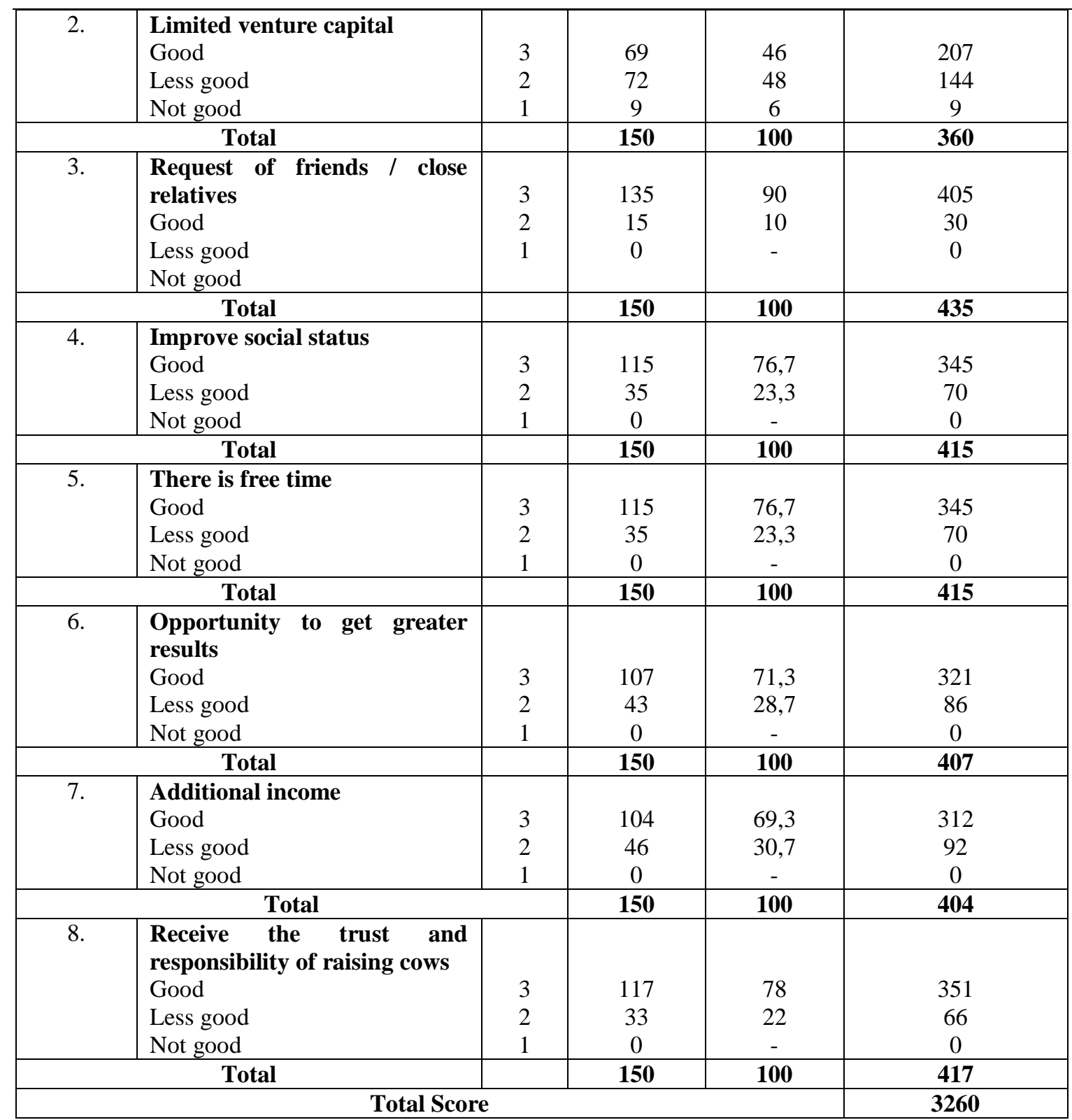

Source: Primary Data after Processed, 2019.

Table 2 shows that the total score of the farmers motivation assessment performed a teseng system consisting of sub variables: (a) the economic demands of the family, (b) limited venture capital, (c) requests of friends/close relatives, (d) improving social status, ( e) there is free time, (f) the opportunity to get greater yields, $(\mathrm{g})$ additional income, $(\mathrm{h})$ accepting the trust and responsibility of raising cattle is $\mathbf{3 2 6 0}$. The results of this study mean that it is in the Good Category (2800-3600). The results of this study indicate that farmers have a good motivation to carry out the teseng system in Bone Regency. The existence of family economic demands is the desire of farmers to implement a system of revenue sharing to meet the economic needs of the family; this is due to the existence of farmers who do not have a job that motivates farmers to do a teseng system. While farmers who already have permanent jobs such as teachers, employees, and others assume that trying to find additional income through trying beef cattle through the teseng system. According to [8], that in general farming is a series of farmer activities that manage the factors of production in the form of land, capital, labor, plants and livestock with the aim of obtaining maximum benefits to meet family needs.

Farmers assume that by doing a teseng system, farmers can earn income so that they can meet the needs of their families. It can be said that the higher the level of needs of family farmers, the more encouraging farmers to do the teseng system. The continuously increasing needs of farmers makes farmers become motivated 
to keep doing a sharing system (teseng) in order to generate profits and meet the needs of farmer families. According to [9], that needs can motivate everyone to do work to meet their needs. Needs will encourage everyone to direct themselves to work to meet their needs or respond to the pressures they experience.

Farmers are motivated by the need to make them fully functional, so that they can reach their full potential. The need will encourage and direct farmers to find or avoid, direct and respond to the pressures they experience. The ability to be able to meet the necessities of life which include meeting primary needs (clothing, food, housing, education), secondary needs (motor vehicles, simple cars) to tertiary needs (recreation/domestic tour). Each level of fulfillment of these needs can also indicate the socio-economic level of farmers. At the level of prosperous or prosperous society can meet the needs of tertiary, while the middle level can meet the secondary needs and lower levels of society in general can only meet primary needs and sometimes even cannot be fully met [9].

Every farmer has a certain size to appreciate something in their environment. Farmers will value something higher or lower depending on their point of view. If a farmer values material wealth more than others, a farmer who has a lot of wealth will get a position at the highest level, whereas a farmer who does not have a lot of wealth will always be at a lower level of society so that it can be said that social status occurs because of something that is appreciated. Social status in social life is a reflection, this is also strengthened by environmental conditions that are natural and hereditary make differences in caste seen in terms of financial and land ownership, farming or the type of business being run [10].

Farmers consider the ease of application of the teseng system and can be said to be very beneficial for farmers. Where the production sharing system (teseng) is a concept of agreement based on aspects of trust between livestock owners and farmers in raising their livestock. According to [11], that the inherited teseng system can increase beef cattle population which supports food security compared to the profit-sharing system with the government pattern.

Influence of Perception and Motivation on Farmers Decisions to Conduct Beef Cattle Business Partnership System (Teseng) in Bone Regency.

Analysis of the influence of perceptions and motivations on the decision of farmers to do a teseng system in Bone District used logistic regression analysis because the dependent variable (Y) is categorical, namely the decision of farmers to do a teseng system was given a value of one and not to do a teseng system was given a value of zero. While the independent variables $(\mathrm{X})$ consists of farmers perceptions $\left(\mathrm{X}_{1}\right)$ and farmers motivations $\left(\mathrm{X}_{2}\right)$.

\section{a. Model Feasibility Test}

The model feasibility test is a test conducted to determine the feasibility of the model of the influence of perception and motivation on the decision of farmers to do a teseng system. To find out like the model of the effect of perception and motivation on farmers decisions to do the teseng system, it can be seen in the Omnibus Tests of Model Coefficients table presented in Table 3.

Table 3. Omnibus Test Coefficient Models

\begin{tabular}{|l|l|l|l|l|}
\hline \multicolumn{2}{|c|}{} & Chi-square & Df & Sig. \\
\hline \multirow{3}{*}{ Step 1 } & Step & 21.688 & 2 & .046 \\
\cline { 2 - 5 } & Block & 21.688 & 2 & .046 \\
\cline { 2 - 5 } & Model & 21.688 & 2 & .046 \\
\hline
\end{tabular}

Source: Primary Data After Processed, 2019.

Table 3 shows that $\mathrm{G} 2=21,688$ with significant $(\mathrm{sig})=0.046$, because $\alpha=0.05>$ sig. $=0.046$ then there is at least one independent variable that influences the model. In the column sig. shows the value of 0.046 which means that the model built is significant and can be continued. Models built on samples are feasible or able to predict population properties. Similarly, hypothesis testing with the Hosmer and Lemeshow Test is used.

The model goodness or goodness-of-fit test can be performed with the Hosmer-Lemeshow method presented in Table 4.

Table 4. Model Goodness Test Results by the Hosmer-Lemeshow Method

\begin{tabular}{|l|l|l|l|}
\hline Step & Chi-square & df & Sig. \\
\hline 1 & 18.745 & 6 & .025 \\
\hline
\end{tabular}


Source: Primary Data After Processed, 2019.

Table 4 shows the sig values (0.025) is smaller than Alpha 5\% so we do not accept the null hypothesis (statistically there is no significant difference between the model and the observed value), because $\alpha=0.05>$ sig. $=0.025$ means that the model is sufficiently able to explain the data, in other words at the $95 \%$ confidence level the logistic binary regression model used is relatively able to explain the data.

Estimation of parameters is done to see how well the model can predict and classify respondents on the dependent variable. Parameter estimation value is obtained by comparing factual Y with estimated Y. The estimation results of the parameters are shown in Table 5.

Table 5. Results of Estimating Parameters for Dependent Variables

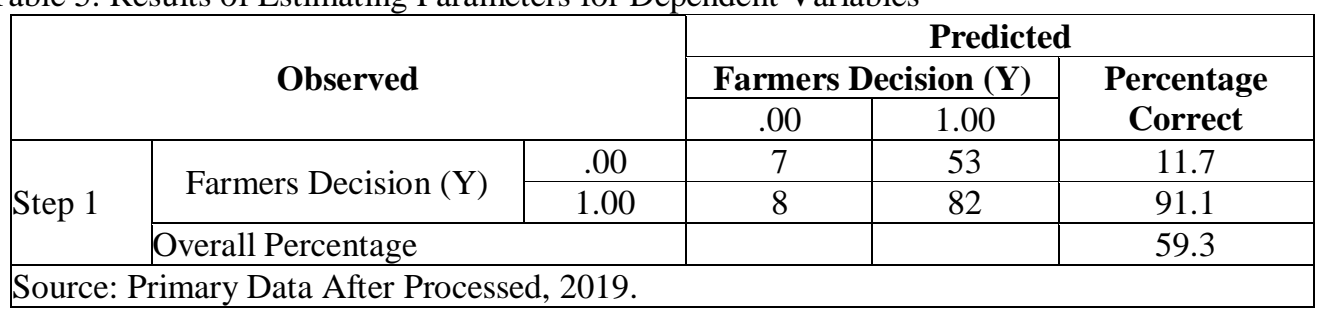

Table 5 shows that Overall Percentage is 59.3, showing that the binary logistic regression model used is able to explain $59.3 \%$ of the actual conditions.

Test the Simultaneous Effect of the Independent Variable

To find out the influence of together the independent variables on the dependent variable can be seen in the summery model table by looking at R Square.

Table 6. Summery Models

\begin{tabular}{|c|c|c|c|}
\hline Step & $\mathbf{- 2 ~ L o g ~ l i k e l i h o o d ~}$ & Cox \& Snell R Square & Nagelkerke R Square \\
\hline 1 & $17.514^{\mathrm{a}}$ & .673 & .758 \\
\hline
\end{tabular}

Source: Primary Data After Processed, 2019.

Table 6 shows that the Nagelkerke R Square column shows a value of 0.758 , which means that $75.8 \%$ of the perception variables $(\mathrm{X} 1)$ and motivation $(\mathrm{X} 2)$ together affect the decision variable of farmers doing a teseng system (Y) and can be explained by the model. And there are other influences outside this model that affect the $\mathrm{Y}$ variable by $24.2 \%$.

Test of Partial Influence of Independent Variables

The effect of independent variables on farmers perceptions and motivations on the dependent variables of farmers decisions is partially presented in Table 7.

Table 7. Variables in the Equation

\begin{tabular}{|c|c|c|c|c|c|c|c|}
\hline & & B & S.E. & Wald & df & Sig. & $\operatorname{Exp}(B)$ \\
\hline \multirow{3}{*}{ Step $1^{\mathrm{a}}$} & X1 & .312 & .105 & 5.754 & 1 & .043 & 1.324 \\
\hline & $\mathrm{X} 2$ & .427 & .273 & 3.852 & 1 & .038 & 1.136 \\
\hline & Constant & -2.758 & 3.167 & .723 & 1 & .395 & .172 \\
\hline
\end{tabular}

Source: Primary Data after Processed, 2019.

Table 7 shows that significant (sig.) Is a number that indicates a significant level of testing individually (partially). Based on the significance of each of the perception variables $\left(\mathrm{X}_{1}\right)$ and motivation $\left(\mathrm{X}_{2}\right)$ are discussed as follows:

1. Farmer perception variable $\left(X_{1}\right)$ has a significant value (sig.) of 0.043. This value is smaller when compared with $\alpha=0.05(0.043<0.05)$, meaning that the perception variable of farmers influences the decision variable of farmers to do a teseng system. Odd ratio (Exp.B) value of 1.324 means that a good farmers perception is likely to make a decision to do a teseng system as much as 1.324 times better. The results of this study indicate that in Bone Regency most of the farmers perceive the teseng system well.

2. Farmer motivation variable $\left(\mathrm{X}_{2}\right)$ has a significant value (sig.) of 0.038 . When compared with $\alpha=0.05$, the value of sig. smaller than the value of $\alpha(0.038<0.05)$, meaning that the motivation variable of farmers 
influences the decision variable of farmers to do the teseng system. Odd ratio (Exp.B) value of 1.136 means that a good farmers motivation will make the decision to do a teseng system as much as 1.136 times better. The results of this study indicate that in Bone Regency most of the farmers have a high motivation to try beef cattle by implementing a teseng system.

Based on Table 7 in column B (Beta) shows the coefficient values to be entered into a binary logistic regression equation are both perception variables $\left(\mathrm{X}_{1}\right)$ and motivation variables $\left(\mathrm{X}_{2}\right)$ have a significant effect on the decision of farmers to do the teseng system $(\mathrm{Y})$ with a logit model that can be formed as a following:

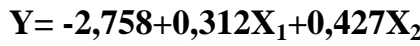

The meaning of the equation is the parameter coefficient on the farmers perception variable $\left(\mathrm{X}_{1}\right)$ and the farmers motivation $\left(\mathrm{X}_{2}\right)$ which is positive shows that the relationship between the independent variable and the dependent variable of the farmers decision to do the teseng system (Y) is directly proportional. This means that farmer's perceptions and motivations of good farmers tend to make the decision to carry out a teseng system. According to [12], that one's perception of understanding an adoption of innovation is to look at the complete picture of producer, agriculture, and practice characteristics to understand how each informs an individual's decision to adopt a particular practice. [13], that motivation is a force that drives someone to do something to achieve the goal. These forces are basically stimulated by the existence of various needs such as: (a) the desire to be fulfilled, (b) behavior, (c) objectives, (d) feedback.

The farmer's decision to carry out the teseng system as an adoption process to accept or reject the teseng system and further confirms the acceptance and rejection of the teseng system. According to [14], that acceptance here implies not just knowing but by actually being able to be implemented or applied correctly and living it and can be observed directly or indirectly by others as a reflection of changes in knowledge, attitudes, and skills. Depending on the process of behavior change attempted, the process of achieving the adoption stage can take place quickly or slowly. Judging from the monitoring of behavior changes that occur, adoption that takes place through a process of persuasion or education is usually more difficult to change. Whereas adoption that occurs through coercion, usually changes more quickly, as soon as the element of coercive activity is discontinued. Meanwhile according to [15], that adoption is a process that occurs since the first time someone hears something new for that person to adopt (accept, apply, use) new things. In the process of adoption, farmers, target farmers take decisions after going through several stages. At first, the farmers-farmers know the target of an innovation that can happen something that is really new or that has long been found but is still new to the target farmers.

The decision of the farmers to carry out a teseng system because the farmers assume that by trying beef cattle will provide benefits both in the form of beef cattle itself and from cow dung that can be processed into manure. According to [16], the high interest of farmers for beef cattle business is triggered by several factors. The high profit factor is the attractiveness of farmers to open beef cattle business. Beef cattle farming business provides a double benefit in the form of weight gain and cow dung in the form of manure. The amount of profit to be gained from the sale of fattened cattle depends on the weight gain achieved, the length of maintenance and the price of a meat (carcass).

\section{CONCLUSIONS}

From the results and discussion, it can be concluded that (1) farmers perception variables on the teseng system which consists of sub variables: (a) economic benefits, (b) technical advantages, (c) easier application of the teseng system, (d) the level of conformity with the local community is in the good category; (2) farmers motivation towards the teseng system which consists of sub variables: (a) family economic demands, (b) limited venture capital, (c) requests of friends/close relatives, (d) improving social status, (e) having time leisure, (f) the opportunity to get greater yields, $(\mathrm{g})$ additional income, $(\mathrm{h})$ accept the trust and responsibility of raising cattle in the good category; and (3) perceptions and motivations have a significant effect on the decision of farmers to do a teseng system.

\section{ACKNOWLEDGEMENTS}

Thank you to the Directorate of Research and Community Service, Directorate General of Strengthening Research and Development of the Ministry of Research, Technology and Higher Education of the Republic of Indonesia for providing research funding assistance with the 2019 Primary University Higher Education (PDUPT) Basic Research scheme. 


\section{REFERENCES}

[1] Sirajuddin, SN, AR Siregar, P Mappigau. 2017. Adoption Rate of Beef Breeders Technology Following Partnership System in Barru Regency. American-Eurasian Journal of Sustainable Agriculture, 11(6), 31-34.

[2] Sirajuddin, SN, AR Siregar, S Nurlaelah, VS Lestari, V Tenrisanna. 2017. The Limitations and Benefits of Partnership Sharing System of Corporated Cattle Market (CCM). American -Eurasian Journal of Sustainable Agriculture, 11(1): 11-14.

[3] Rohani, ST, SN Sirajuddin, IM Saleh. 2013. Public Perception on Tesang Production Sharing System in Beef Cattle Business in Bone Regency. Social Economics of Animal Science. Faculty of Animal Science. Hasanuddin University. Makassar.

[4] Sugiyono. 2014. Statistics for Research. 24th Print. Alfabeta publisher, Bandung.

[5] Sirajuddin, SN, M Aminawar, S Nurlaelah, A Amrawaty. 2015. The Application of Tesang Sharing System at Cattle Farm in Indonesia. Proceeding. The Third International Seminar on Animal Industry.Sustainable Animal Production for Better Human Welfare and Enviroment. Faculty of Animal Science.Bogor Agriculture University.pp.400-420.

[6] Asnawi, A, A Amrawaty, Nirwana. 2017. Local Culture and Ability to Access Funding on Beef Cattle Farmers. American-Eurasian Journal of Sustainability Agriculture, 11(5): 18-23.

[7] Sirajuddin, SN, S Nurlaelah, A Amrawaty. 2016. Income Analysis of Beef Cattle Breeders for Traditional Profit-Sharing System (Tesang) in South Sulawesi Province, Conference Proceeding, Vienna-Austria, 18(6):1539-1542.

[8] Agung, KS, S Djaelani, W Rini. 2009. Community Empowerment through the Beef Cattle Gaduhan Project in Central $\mathrm{Oba}$ and North $\mathrm{Oba}$ District, Tidore Island, North Maluku. Animal Science Bulletin Vol. 33 (1): 40-48, Faculty of Animal Science, Gadjah Mada University, Yogyakarta.

[9] Maryati, S. 2009. Factors Influencing Community Preference in Choosing Vocational High Schools (SMKN). Semarang: Post-Graduate Program master's in urban and Regional Development Engineering at Diponegoro University.

[10] Ahira, A. 2012. Socio-Economic Status of the Community. http // www-acne-ahiara .- / com.status.social.ekonomi.masyarakat. Accessed 9 September 5, 2014.

[11] Sirajuddin, SN. 2013. The Role of Teseng (Traditional Profit-Sharing System) in Increasing Beef Cattle Population, in Bone Regency, South Sulawesi Province. Faculty of Animal Science. Hasanuddin University, Makassar.

[12] Reimer, P Adam, DK Weinkauf, LS Prokopy. 2012. The Influence of Perceptions of Practice Characteristics: An Examination of Agricultural Best Management Practice Adoption in Two Indiana Watersheds. Journal of Rural Studies, 28 (19) : 118 - 128. Accessed September 17, 2018.

[13] Uno, HHB. 2009. Motivation Theory and Measurement. Jakarta: Publisher Bumi Aksara.

[14] Mardikanto, T. 2009. Building a Modern Animal Husbandry. UNS Press, Surakarta.

[15] Sirajuddin, SN, A Asnawi, S Syawal, M Jamal. 2016. Response of Cattle Breeders to Rice Straw Silage in Soppeng Regency, South Sulawesi Province. American Eurasian Journal of Sustainable Agriculture.10(3):33-36.

[16] Rianto, E dan Purbowati, F. 2009. Complete Beef Cattle Guide. Penebar Swadaya, Jakarta. 